\title{
Article
}

\section{The Good City}

\section{Counterterrorism and the Ethical Work of Transformation in Copenhagen}

\author{
Stine Ilum \\ University of Copenhagen
}

\begin{abstract}
In 2016-2017, a number of terrorist attacks took place in public spaces in cities across Europe. Following this, numerous concrete blocks were placed in the streets of Copenhagen in order to prevent similar attacks made with vehicles towards people in the public spaces of the city. For the Municipality of Copenhagen, the concrete blocks became the first step in a long process of dealing with the question of how to best secure the city's public spaces. To the municipal employees, the concrete blocks made Copenhagen's public spaces express negative moral values such as hostility and fear. Therefore, the employees initiated what I will call an ethical work of transformation by shaping the concrete blocks into measures more in line with the moral values they associated with a good city. Where literature on security point to a worldwide increase in security measures, often legitimized by way of moral discourses of protecting democratic values and saving lives, this article provides an example of a counter movement, where a public institution mobilized moral discourses and values associated with liberal democracy and the welfare state in order to minimize the presence of security measures in the public space. By following the ethical work of transformation of the security measures, the article further shows how moral values and materiality are intertwined. Adding this material dimension to literature on morality/ethics sheds new light on discussions of security, as security measures become more than mere material inventory in the streets, they become a manifestation of certain moral values in the city.
\end{abstract}

\section{Keywords}

counterterrorism, public space, security measures, morality/ethics, materiality, the good city

\section{Introduction}

One morning in December 2016, the Danes woke up to a new sight in the urban landscape. Overnight, numerous concrete blocks had been spread across the inner 
city of Copenhagen. Soon after, the blocks were also found in other large cities in Denmark, not to mention in most cities across Europe. The previous year a number of terrorist attacks took place in public spaces and buildings in Europe. Just to name a few, in the summer of 2016, a truck drove down the crowded Promenade des Anglais killing 85 people celebrating Bastille Day in Nice. And in December 2016, another truck drove into a crowded Christmas market in central Berlin killing 12. Following the latter attack, the Danish Security and Intelligence Service (PET) and Copenhagen Police told the Municipality of Copenhagen to put up concrete blocks around Christmas markets as a way to prevent similar attacks using vehicles to target large groups of people. Eva, a project manager from the municipality's Technical and Environmental Department (TED) recalls:

PET and Copenhagen Police called and said: 'We need to put up something around the Copenhagen Christmas markets, it has to be concrete blocks, and it has to be now.' Then lots of blocks were put up in the city, but when the Christmas markets were over, the message was: actually, we can't just remove the blocks yet, in fact we need to put up even more.

For the municipality and the TED employees, this became the first step in a long process of dealing with the ongoing terror threat and the question of how to secure the city's public spaces. In other cities in Europe, vehicle attacks kept happening - at the Rambla in Barcelona, at London Bridge, at Drottninggatan in Stockholm - and in Copenhagen the streets were soon full of concrete blocks. For the Danish decision makers, the continuous attacks in other cities and the security agency's assessment that similar attacks could happen in Copenhagen, constituted the obvious basis for legitimately increasing security and turning the concrete blocks into permanent and more extensive security measures. However, in the eyes of TED employees, the concrete blocks signaled a situation of risk and war and made Copenhagen's public spaces express negative moral values such as hostility and fear. So, instead, the TED employees initiated what I will call an ethical work of transformation by carefully and step-by-step shaping the concrete blocks into security measures more in line with the moral values they associated with Copenhagen's public space. In this process, the ethical work of transformation took material form, and thereby moral values became immanent to the materiality. Moral values associated with liberal democracy and the Danish welfare state, such as community, openness, inclusiveness, and spaciousness. The TED employees thereby drew on long-term Danish traditions for shaping public spaces in a specific material way and engaged moral values in order to recreate what they believed is the good city, despite the increased security level.

This article is based on a year of ethnographic fieldwork conducted in 2018-2019 among professionals working with counterterrorism in Copenhagen. The fieldwork included the Municipality of Copenhagen and the Danish Security and Intelligence Service, as well as the public spaces in the inner city of Copenhagen. I have conducted fieldwork in both of these arenas in order to explore the dialectic 
between the materiality of security installations in the streets and the work processes and decisions in the offices of public organizations, thereby showing how the moral values that decision makers associate with the good city are actualized in public space and are intertwined with the material form of counterterrorism measures.

Scholars from across disciplines argue that we are currently experiencing times of increased alertness, fear, and focus on security (Goldstein 2010; Hesterman 2018; Klauser 2017; Maguire et al. 2014; Minton 2009; Sorkin 2008). Urban fear plays a key role in this security moment as cities are seen as targets for many threats, including terrorism. According to Jon Coaffee, 'The message from governments in many Western states [...] is disseminated widely: defense of the city - of the places where people work, relax and live - is [...] central to wider national security' (Coaffee 2009, 345). Along this line of analysis, the terror threat towards cities has more recently been directed at so-called soft civilian-centric targets, in particular everyday public spaces and crowded areas such as shopping promenades (Coaffee 2009, 345; Hesterman 2018, 2). As a result, security measures in urban public spaces are increasing; more areas are surveilled, barriers and walls are built, and police, soldiers, and private guards patrol the streets, allegedly to defend Western values such as freedom and democracy (Low 1997; Peterson 2006; Sorkin 2008; Simpson et al. 2017).

Some scholars argue that the concept of security is (mis)used by decision makers to authorize and take extraordinary actions in response to possible threats, which ultimately legitimizes the breaking of rules - all in the name of security (Buzan et al. 1998, 25; Goldstein 2010, 492; Maguire et al. 2014, 1). Moral discourses and the power of fear are said to be mobilized to justify more security measures and legitimize increased spending on defense (Fisher 2013; Goldstein 2010). According to David Fisher (2013), moral language and claims of humanitarianism are used by policy makers as well as political and military leaders to gain support for their causes and justify their actions; a famous example is the legitimizing of the Iraq war by way of moral claims of security, humanitarianism, and international responsibility to stop a regime that, according to the U.S. State Department's Bureau of Public Affairs, 'developed and used weapons of mass destruction, that harbored and supported terrorists, committed outrageous human rights abuses, and defied the just demands of the United Nations and the world' (Fisher 2013, 142; Lenz 2020). In short, it is the argument of much security literature that initiatives taken in the name of security are increasing, and that decision makers legitimize this increase by way of the power of fear and moral discourses of humanitarianism, protecting democratic values, saving lives, and so on. In the case of Copenhagen, however, moral values related to the urban public space, welfare state, and liberal democracy have not been mobilized in order to legitimize more security. To the contrary, decision makers have used these moral values as a point of orientation in their ethical work on minimizing the presence of security installations in Copenhagen and in recreating what they believe constitutes good public spaces. The power of fear has, if anything, sparked off this process. So, where the broader lit- 
erature on security and securitization points to how security measures increase hand-in-hand with moral discourses, unimpeded, this article sheds light on a moral countermove to unwarranted security measures.

The empirical setting for this countermove is the Danish capital, Copenhagen. A city that has a strong tradition for developing its public spaces and has received much positive attention in the past decades for its pedestrian and bicycle friendly layout, urban nature and gardens, its aesthetic design and architecture. However, in December 2016 the appearance and character of many public spaces changed, as a consequence of the raw concrete blocks scattered around the city. In this article, I examine how the blocks became a matter of serious concern to the TED, because they interfered with the moral values the employees associated with the city's public spaces. The arrival and the presence of the blocks provoked what Jarett Zigon (2007) called a 'moral breakdown' at the TED. According to Zigon, morality is a mode of unreflective being in the world that is, however, never completely static (Zigon 2007, 134-136). The element that allows morality to be open to the world is the so-called breakdown, which occurs in moments of ethical dilemma and calls on the performance of ethics (ibid. 137). Zigon concludes that the primary goal of ethical work is to return from the uncomfortable moment of breakdown, and back into the unreflective comfort of familiar morality. Zigon's theory on moral breakdowns and the performance of ethics provides a useful framework for understanding how ethics come into play in a state of exception and in the case of my study, for arguing that the sudden appearance of the concrete blocks in the streets of Copenhagen sparked off a moral breakdown at TED, which urged for decisions and elicited ethical work of transformation in order to recreate good public spaces.

As part of this ethical work process, the appearance of the concrete blocks underwent a physical transformation. I will argue that the material change reflects an ongoing ethical work of transformation practiced by employees at TED. In this context, ethical work of transformation refers concretely to the process of reconfiguring the counterterrorism installations so that they, step-by-step, became more in line with the moral values that TED employees associate with Copenhagen public spaces. To understand this ethical work of transformation, I draw on Michel Foucault $(1984,1997)$ who has been a leading figure among the scholars in anthropology who have focused on virtue ethics and projects of self-cultivation and self-formation (Mattingly and Throop 2018, 480). According to Foucault, morality is, on the one hand, made up by a set of communal values specific to the historical and social context, and on the other by individual ethical practices of cultivating virtues (Faubion 2001, 85; Foucault 1984, 25-28; Laidlaw 2017, 8). In other words, general moral values are relatively stable over time, but individuals have a degree of freedom to form themselves as ethical subjects (Mattingly 2012, 164). I have found that this distinction between morality and ethics is useful for understanding the dynamic aspects of TED's ethical work in the context of a more stable morality shaped by the Danish historical and social setting. However, while literature on virtue ethics ascribe ethical work to the individual, in this arti- 
cle, I would like to take Foucault's idea about ethical formation practices to a city level, and argue that individuals can not only perform ethical work on themselves but it can also be done on a city. I will refer to this as an urban morality. My aim is, therefore, not to look into the self-formation of TED employees, but their ethical work done to form Copenhagen as a good city. Furthermore, I add an attention to materiality to Foucault's idea of ethical work. In the past decades, much anthropological attention has been given to the relation between people and the material world (Appadurai 1986; Miller 2010; Sjørslev 2013); both Zigon and Foucault present moral values and ethical work as elements of mental practice. In this article, I will look into the way that moral values, ethical work, and materiality can be intertwined. Adding this material dimension sheds new light on discussions of security, as security measures become more than mere material inventory in the streets, they become a manifestation of certain moral values in the city.

The article thus argues that a moral breakdown, caused by the sudden appearance of concrete blocks in the streets, has elicited an ethical work of transformation at TED in order to recreate the good public spaces of Copenhagen. In this process, moral values associated with liberal democracy and the welfare state serve as a counterweight to arguments for more visible security and as guiding principles in the reshaping of counterterrorism measures in the public space. To describe this process, the article first turns to the offices of the Municipality of Copenhagen to provide an understanding of the employees at TED and the work they normally do on public spaces; then their actions and concerns in light of the terrorist threat and the arrival of concrete blocks will be presented, and finally we will follow the transformation of the concrete blocks in the streets of Copenhagen.

\section{Shaping the Good City}

As part of the Municipality of Copenhagen, TED is responsible for developing, constructing, and maintaining the city's public spaces, including roads, bike lanes, sidewalks, pedestrian streets, plazas, harbor fronts, parks, and cemeteries. TED consists of 2,050 employees, from architects to anthropologists and gardeners to refuse collectors. Only four or five of these people work specifically and full-time with counterterrorism, along with a few externally hired consultants and operations personnel maintaining the actual security measures in the streets. None of these employees worked with counterterrorism or even with security before the concrete blocks landed in the streets, so taking a look at the type of work they did before provides a good basis for understanding their perception of Copenhagen's public spaces and their approach to securing them.

Prior to the fieldwork I base this article on, I worked as a consultant on a number of projects for TED. These projects involved: developing expressways and signposting for bicyclists, encouraging cleanliness in public spaces, providing room for tranquility and absorption in public spaces, and developing a nature reserve that would accommodate everything from cyclists, pedestrians, playing children, and beekeepers to swans, biodiversity, and climate adaptation solutions. Looking at this 
selection of projects provides a basic understanding of the type of work TED employees engage in daily, and gives an idea of the values they strive for when shaping the city's public spaces; namely, green and clean spaces that encourage tranquility as well as play, where there is room for everyone, and which are secured against climate change in a way that simultaneously creates value for nature and everyday life. Year round, employees at TED work specifically on improving the city's public spaces, both by maintaining existing spaces and also by developing hundreds of new projects like the ones described above. To ensure progress, they continuously set new goals and overall visions for TED's work on the city.

Before Eva became the project manager and responsible for developing new counterterrorism initiatives, she worked with sustainability and green initiatives in Copenhagen for about twenty years. In that time, she also developed the 2025 vision for TED, called Fællesskab København (Community Copenhagen), that describes common priorities and goals for their work. A vision that begins like this:

We can be proud of Copenhagen. We have created a city [...] known all over the world for its environmental and climate effort, we are the best bicycle city in the world, a showcase of Danish architecture, but most importantly, Copenhagen is a good place to live an everyday life. A city that works. This success has not happened by coincidence. It is the result of many years of purposive work of developing the city - with the Copenhageners and the life between buildings as its pivotal point.

(Municipality of Copenhagen 2015, 1, author's translation)

In the time Eva has worked for TED, she has furthermore developed the municipality's architecture policy, called Arkitektur for Mennesker (Architecture for People), which sets the direction for the architectural development of the city:

Architecture is created for and by people and sets the physical frame for our common and individual lives [...] The architecture policy focuses on creating eye contact between people $[. .$. It takes the human scale of life into account [...] The architecture policy insists on thinking of public life before public space and public space before buildings in a way that sets the frame for community but also for diversity and individual needs.

(Municipality of Copenhagen 2017, 6, author's translation)

TED's employees have for years worked concertedly on shaping a city they can be proud of. A city where public life and public space are key. By continuously setting goals, developing new projects, and evaluating progress, employees at TED strive for what they believe is the good city. Broadly understood, ethics and morality are about the way people strive for something better, for happiness, for the good, to 
live well (Faubion 2001, 85; Laidlaw and Mair 2019, 329). However, where literature on virtue ethics presents ethical work as the individual's self-forming practice, employees at TED, in a similar way, strive for the good in an ethical transformation of the city. Taking Foucault's framework to a city level is therefore useful for understanding how TED employees, through years of cultivating certain moral values, have physically shaped what they believe is a good city. The physical environment and materiality have not been central to anthropological literature on morality and ethics, but when engaging with people whose work it is to shape the material world, it becomes evident that moral values are embedded in the materiality they give shape to. Characteristic of TED's work with public spaces is, on the one hand, a cultivation of moral values such as community, inclusiveness, openness, and spaciousness, and on the other, a shaping of the materiality of the city in specific ways, including a bicycle and pedestrian friendly layout, a human scale, and green solutions. The moral values and materiality of the city are closely intertwined, because materiality is the medium through which TED employees seek to shape the moral values associated with public space. For TED employees, shaping the good city is therefore made up both by the cultivation of certain moral values as well as the associated materiality. The urban morality thereby comes to be reflected, over time, in the city's physical landscape. In the following we will take a closer look at which moral values and associated materiality constitute Copenhagen's urban morality.

\section{Community, Inclusiveness, Openness, and Spaciousness}

In today's Copenhagen, the distinct urban morality and matching urban landscape may be taken for granted as mere products of the Danish historical and social context, but individual Copenhageners have been cultivating specific moral values for years, at TED as well as other institutions. Eva and her many colleagues are examples of such individuals, but they are preceded by many more. What stands out in the TED projects I participated in, in TED's vision for 2025, and in their architecture policy, is a pronounced focus on the people in the public spaces, the human scale of life, and life between buildings. This is not a coincidence but is the result of many years of focused work. When life between buildings is emphasized as a pivotal point in TED's work, it might sound strange — or as a bad translation on my part: why not just write 'the public space'? However, it was the Danish architect, Jan Gehl (1971), who coined the concepts of 'life between buildings' and 'the human scale' in Copenhagen in the 1970s. Gehl has spent a lifetime advocating for public spaces planned for people and street life instead of cars and traffic. By referring to the human scale and the life between buildings in their visions and policies, TED underlines the importance of making public spaces inviting for people, but also refers to the many individuals before them who have cultivated specific moral values in relation to Danish city planning and thereby, over time, developed the urban morality of Copenhagen that we see today. To understand TED's work with counterterrorism in public spaces today, it is therefore crucial to understand the considerable work on public spaces that precedes it and therefore shapes its moral values. 
From the ancient Greek discussions in the agora, over the 17-18 th century's development of capitalism and a liberal public sphere, to the past decade's Arab Spring demonstrations, the city and its public spaces have played a special role in relation to democratic values and the freedom for private people to meet physically, discuss matters of common concern, gain power, and thereby be able to act (Arendt 1998[1958], 198-200; Bundegaard 2019, 436; Habermas 2009[1962], 51, 7579). There is no doubt that Copenhagen's urban morality is based, at its core, on the ancient Greek idea of a public meeting place and the liberal democratic freedom to meet and discuss; but there are, in addition, certain moral values and types of materiality that are specific to the Danish public space. Following World War II, modernistic urban planning encompassing certain ideas and objects prevailed all over the world as well as in Denmark: efficiency, streamlining, suburbs, infrastructure, cars, expressways, and parking lots, to name a few. Inspired by Jane Jacobs (2011[1961]) from NYC, a number of Danish architects - Gehl included - started to criticize modernistic planning and encourage a city of smaller buildings, narrower streets, and more intimate public spaces designed for the way pedestrians and bicycles experience and move in the city - ultimately, to invite to more street life and informal meetings (Gehl 2013, 8). During the next decades, the movement gained strength and pedestrianized public spaces were developed all over Denmark. In the beginning of the 1990's a research project and publication called Bedre Byrum (Better Public Space), led by four of the leading figures in this movement, Jan Gehl, Lars Gemzøe, Bo Grønlund, and Steen Holmgren (1991), analyzed the pedestrianized public spaces in 91 Danish cities. In the publication containing lots of photos of good and bad examples, the four architects review Danish public spaces in order to learn and to establish what - in their opinion - constitutes the good public space and thereby to further develop the Danish tradition for creating public spaces. Some of the values they emphasize as key are: coherence and openness, e.g. there should not be too many types of paving or too much street furniture, there should be room and activities for everyone, children, young, elderly, and people with handicaps; and there should be plenty of seating and other types of meeting places, especially in the sun (Gehl et al. 1991). To follow up on the research project, the Danish philanthropic association, Realdania, initiated a large architectural competition in 2002 under the same name - Bedre Byrum (Better Public Space). In the introduction to the competition the editors underline that in order to consolidate a Danish practice for creating better public spaces, municipalities were invited to propose concrete development projects and apply for funding. The editors emphasize that the so-called 'better public space' should, most importantly, function as a meeting place for people, but furthermore:

The better public space refers to a feeling of social community. It is a liberal and spacious place that can accommodate a respectful meeting between strangers. [The better public space is] welcoming. Whether you pass by or make a stop, it is open and invites to different activities. [The better public space] maximizes the experience of nature. Weather, daylight, circadian rhythm, and seasons influence its elements. 
Stine Ilum - The Good City

(Andersen et al. 2002, 4-5, author's translation)

The virtue ethical distinction between the moral as the more static values and the ethical as a more individual work of transformation, provides a useful frame for understanding how the Danish historical and social context sets the frame for TED employees' work with public space and counterterrorism measures today. In the past century, architects and city planners have, through ethical work, shaped the idea of what a good city constitutes. And today's architects and urban planners at TED base their work on a now consolidated practice for creating good public spaces, but at the same time set new goals to ensure the continuous development of the urban morality and an even better city. The good city and its public spaces are, on the one hand, associated with moral values such as community, openness, inclusiveness, and spaciousness, and on the other, a shaping of the concrete materiality of the city, including a bicycle and pedestrian friendly layout, a human scale, presence of nature and green solutions, coherence, and room, activities, and seating for all. Where the materiality is specific to the work with public spaces, the moral values such as community, openness, inclusiveness, and spaciousness are according regional ethnographic studies - associated with Danish society more widely and are practiced, or at least striven for, in different types of public spaces as well as in public institutions (Anderson 2008; Krøijer and Sjørslev 2011; Løfgren 2015; Stanfield and Riemsdijk 2019). For instance, in Sally Anderson's (2008) study of Danish sport associations she argues that Denmark's egalitarian ethos, history of social tolerance, and the welfare morality that believes in making room for all is reflected in the upbringing of children through sports. The urban morality of Copenhagen is in this way a reflection of wider societal values of liberal democracy and the welfare state, including community, inclusiveness, openness, and spaciousness, values embedded in the work of TED employees as well as the materiality of the city.

The following paragraphs are interlaced by snippets of fieldnotes, observations, and interviews conducted through a period of two to three years, and will therefore not only take you through different urban spaces of Copenhagen and introduce you to the concrete blocks, but also through different periods and stages of TED's development of counterterrorism measures, providing the background for understanding how these security measures challenge the employees' perception of a good city. When reading this, it is important to keep in mind the specific urban morality of Copenhagen and the effort and dedication it has taken to create the public spaces of today.

\section{The Arrival of the Concrete Blocks}

It is December 2016. The first time I see them is on a cold morning on my way to work. The concrete blocks. I have worked at the same office for about two years, and I take the same route on my bike every morning: I cross the busy square by Nørreport Station - where all Copenhagen's buses, trains, subways, and therefore morning commuters meet - then I continue down Frederiksborggade, and even 
though it is a pedestrianized street I am usually in such a hurry that I do not bother to get off my bike, so I slalom around the many people as I make my way to office. This morning is different. As I am about to turn right, I see that the entrance to the pedestrian street is closed off by concrete blocks. They are about two meters long and half a meter wide and tall, they are painted white, and have the municipality's logo stamped in dark blue on the side. It is obvious that they have been used somewhere before because the concrete is cracked, and the paint is scratched off. Some of them also have graffiti tags painted on the sides. I have seen these types of concrete blocks many times before, as they are normally used to close off construction sites. I get off my bike as I make my way around the blocks and into the flow of people who navigate around them. People obviously notice the sudden presence of the blocks, as they create a bottleneck in their morning flow but like on all other mornings, people continue down Frederiksborggade at a fast firm pace on their way to work. It is a cold morning and people are wrapped in thick coats and scarves, Christmas garlands with bright red hearts hang across the street, and I weave the rest of my way to the office. The same day, newspapers report that all Christmas markets and central pedestrian streets in Copenhagen have been closed off to prevent terrorist attacks using vehicles. The municipality has done this using two types of concrete blocks; a small version like the one at Nørreport and a larger, almost one-and-a-half-meter tall version in rough, grey concrete placed around the city hall square and the Nyhavn Christmas market (Astrup 2016).

In the streets of Copenhagen people notice the arrival of the concrete blocks - but continue their daily routines. The newspapers report about it - but not as breaking news or headline of the day. At TED, however, the arrival of the concrete blocks creates a much stronger reaction. Aja, an architect and city planner who, prior to working with counterterrorism, worked with evaluations of public life in Copenhagen, describes her experience of the day the blocks arrived:

I wanted to do something overnight. To reverse what had been done. We [employees at the TED] woke up and thought: What is that? And we agreed that it could not look like that, we had to do something. I mean, it is almost an alienation of our city to do such a thing. [...] One thing is the small concrete blocks, but the horrible ones were down at Nyhavn. They were war-like monuments [...] It had become very hostile, a hostile city. And Copenhagen is an open city, there is room for everyone, we have to be able to move around the city, to walk, and be among each other.

Like other TED employees, Aja describes the arrival of the concrete blocks as almost an assault or a violation of the city. Not a violation of herself as a person but a violation of her city. It is not her personal morality but her urban morality that is being challenged here, the moral values associated with public space. The blocks remind her of war, risk, and outright hostility. Completely different moral values 
than the ones she normally associates with Copenhagen. Thereby, the concrete blocks, in her eyes, cause an alienation of the city. This may seem like a strong reaction to a few concrete blocks. However, knowing how moral values associated with the good city are intertwined with the materiality of public space, to TED employees the concrete blocks are more than their material form, they are material statements of alien moral values. After the instant shock, the employees at TED express an instant urge to do something about what has happened - to reverse what has been done - but they are not sure what to do. In Zigon's words, the employees were faced with an ethical dilemma of the need for increased security versus the urge to maintain good public spaces. A moral breakdown had occurred, and now was the time for TED employees to perform an ethical work of transformation aimed at a restoring of the good city - and thereby the harmony between values associated with particular materials and with the wider society.

One of the first things the TED employees did was to start writing a memorandum for the politicians to decide on how to go about dealing with this new phenomenon in Copenhagen. Two years after writing the first memorandum Anette, a landscape architect from TED, reflects on the writing process:

What do we do now? What sort of assignment are we actually facing? It was a pretty complicated memo to write, because there were many things people wanted included, but it was also a complicated time. You know, now time has passed, but back then there was no language for what this was. And more [attacks] kept happening. [...] there was an atmosphere of: this will just keep on coming, it won't be long now. And at the same time there was no real language for it. How big is this? What does it entail? What will the city look like? Are we in the process of building a fortress city?

Professionals who until recently had worked on pedestrian, bicycle, park, or climate projects, which added to the idea of the good city, were suddenly working on a security project that revolved around raw concrete blocks. Those working on the memorandum were experienced people who had developed visions and strategies for the entire department, but suddenly they had no idea how to deal with a simple concrete block standing in the street. Based on the work of Martin Heidegger, Zigon describes a moral breakdown using an analogy of hammering, which in many ways is similar to the thoughts of Anette when writing the first memorandum. Usually when one uses a hammer, one is just hammering and does not reflect upon the process, what a hammer is, how to use it, or what it means to be a person using a hammer. Then the hammer head comes loose from its handle. This is the breakdown. One must suddenly reflect on the process of hammering. Can I continue with a loose head? Should I fix it or buy a new one? One might also notice that one's arm is a bit sore, the hand is sweaty, and so on. As Zigon argues, the moral breakdown is a mode of stepping away from the familiar and having to figure out and work through the situation on more fundamental terms: What sort of 
assignment are we actually facing? How big is this? What does it entail? What will the city look like? Are we in the process of building a fortress city? (Zigon 2007, 137). TED employees had previously given shape to the city's public spaces for decades without hesitation, but then an alien element lands in the streets, a moral breakdown happens, and they started to reflect on the fundamental process of shaping the city. The questions Anette presents are not just about a concrete block at street level but about moral values at city and society level. And the same goes for Aja's perception of the city, that has gone from open and democratic to alien and hostile.

In this way, the sudden presence of concrete blocks in Copenhagen elicited fundamental ethical reflections on city and society that demanded ethical work in order to return to the comfort of the familiar morality. In the following I will take a closer look at the ethical work process that unfolded through the next years at TED and in the streets of Copenhagen.

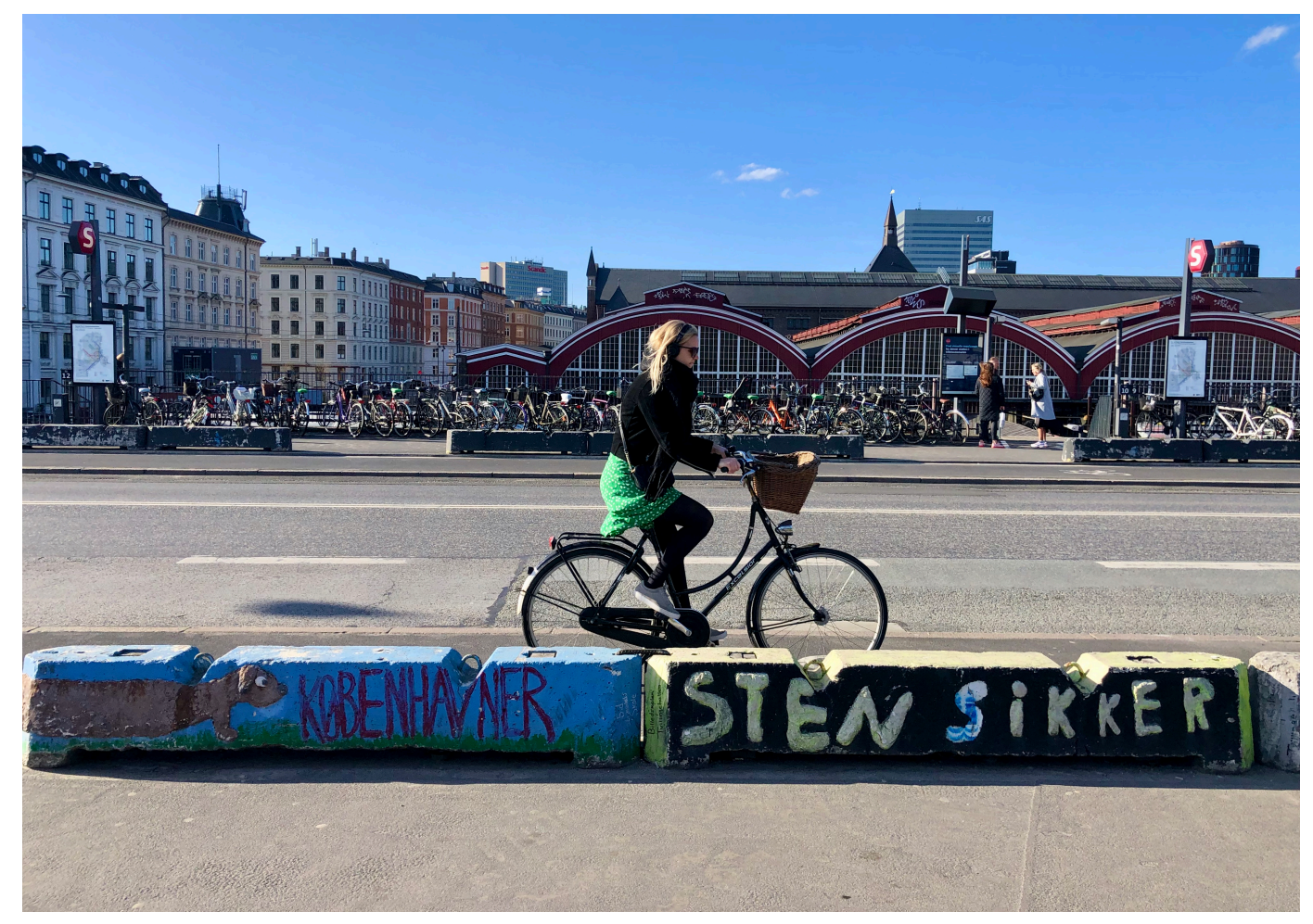

'Copenhagener' and 'Rock-solid' - Two concrete blocks decorated by local children in Copenhagen. Photo: Stine llum.

\section{The Ethical Work of Transformation}

It is June 2017. It has now been half a year since the concrete blocks landed in the streets of Copenhagen, and I am standing at the city hall square in the center of the city. It is noon and is raining slightly, like any other typical summer day in Denmark. On the buildings surrounding the square are neon-lit billboards and 
commercials, the noise of traffic is constant from the adjacent six-lane road, and there is a continuous stream of people crossing the square, but very few stop or sit down. Except for the many Asian tourists gathering around the Hans Christian Andersen statue to get their picture taken. Half of the square is closed off due to the construction of a new subway stop, a new bicycle lane, and what the newspapers have called a 'forest' on the city hall square - about thirty trees of five different species (Kraul 2019). Along the southern side of the square, parallel to the sixlane road, stand four concrete blocks - the tall version. Graffiti tags and concert posters have been plastered on the grey concrete of three of them, while the third is covered in larch wood shaped as a bench on the one side and a bike rack on the other. On top of the bench is a planter box where Indian cress, tansy, and some orange and yellow flowers are growing. The papers report that a small company, which specializes in developing urban gardens, has received a minor grant from the municipality to develop the idea of a cover for the concrete blocks and are testing it here at the city hall square (Melander 2017).

It is October 2017. I am walking from the city hall square down Copenhagen's main pedestrian street, Strøget. Where the pedestrian street starts there used to be four concrete blocks - the tall version - but now there are five or six roughhewn granite blocks. They are dark grey and are about one and a half meters long and half a meter wide and tall. The flow of people is condensed here, as the street is rather narrow and people walk slowly, examining the shop windows. After a few hundred meters the narrow street opens up into a large square with a renaissance fountain in dark grey marble and bronze. The square is covered with old cobblestones and surrounded by $18^{\text {th }}$ century buildings. Around the square I see the concrete blocks again - now the smaller version - but they are not white and cracked like they used to be, they are freshly painted in bright colors. One is painted green and has a huge mouth on the side, full of wobbling teeth, and the statement, 'Does not wobble'. Another is painted light blue with palm trees and the words, 'Vamos amigo'. A third is painted completely black, with capital letters saying, 'IN THE WAY'. Eva from TED tells me that some of the concrete blocks were decorated by children from an art school, while the rest were just painted grey. A specific grey color from the municipality's design manual. Eva explains,

It's the design manual that says that things have to be in keeping with their surroundings. With this manual one makes a dedicated effort to make things look homogenous, so [...] there's a sort of consistent line in the look, it is recognizable, and it is neat and nice. The places where we couldn't put up planters or granite blocks because there wasn't room for them, we left the concrete blocks standing and painted them in this grey. Nobody was really happy with this solution but it was the best we could do.

It is August 2018. I am back at Nørreport station. It is summer, afternoon, and an unprecedented heat wave has hit the city. A woman in her mid-30s whizzes by on a cargo-bike with a little girl sitting in front. They both have blonde hair and are 
wearing sunglasses. Nørreport is an outdoor station with stairways leading down to the underground tracks. It has recently been renovated, which made more space for pedestrians and bicycles, but the station is still surrounded by car traffic. The concrete blocks that I met here for the first time a winter ago, are now gone. Instead, the entire station area is closed off with granite blocks and large black metal planters. The granite blocks are bigger than the concrete blocks used to be, but they are made out of rough-hewn grey or rose-pink granite and several of the TED employees have underlined the fact that they have previously been used at the harbor and some of them have even made up the old staircase to the National Gallery. Some of the planters are round and have a small tree surrounded by ivy planted in them all year. Others are flat and are filled with seasonal flowers. Last winter they were filled with spruce branches, in spring they were filled with forsythia and orange and yellow pansies, now they are filled with a sort of red exotic flower that I do not know the name of. Two women have placed a stand next to one of the planters, from where they hand out Jehovah's Witness leaflets, a man is sitting on one of the granite blocks eating his McDonald's burger, and more bikes whizz by.

Based on the memorandum written by Anette, TED received funding in fall 2017 for three initiatives regarding counterterrorism measures: to analyze if parts of the city center could to some extent be closed off to vehicles, to develop prototypes of reinforced street furniture, making stronger versions of the already existing street furniture, and to beautify existing installations, including the two types of concrete blocks. The first two projects had longer time frames and were contracted out to consultants. The third project started as soon as funds were disbursed. Through 2017 to 2018, the physical appearance of the concrete blocks changed from scratched white concrete, to painted design-manual-grey, child-decorated multicolor, rough-hewn granite blocks, to large black metal planters. Here and there ideas were tested; a larch wood bench filled with plants by the city hall and a bench fixed to the ground at Strøget. What is worth noticing is that the security measures were transformed in a very specific way: they became more in line with the urban morality and the associated materiality of Copenhagen. The concrete blocks became more coherent with the rest of the city as they were painted grey, they became greener and more climate friendly as they were filled with plants and trees, and they became more inviting and made room for all as they were turned into benches and granite blocks to sit on. And with humor and color the blocks went from warlike and hostile to people-friendly and even fun. The same moral values and materiality city planners and architects had used in the ethical work of transformation of the city for years came into play in the ethical work of transformation of the concrete blocks. Thereby, TED employees used moral values associated with the good city as a point of orientation in their ethical work on minimizing the presence of security installations in Copenhagen. Aja describes the process like this:

We had to take a look at our design manual and see if there was anything we could use to make it a Copenhagener-solution [...] 
and then we went at it as specialists and said: okay this public space functions like this, it is part of this hierarchy, there are these edge zones, and this flow - how can we replace some of the concrete blocks with something one can sit on or something aesthetically more palatable? [...] and then we went to the police and said, is this secure enough? And they nodded. So, what you see in the streets today has been approved by them $[\ldots]$ but we tried to install as few as possible.

In addition to transforming the counterterrorism measures to bring them in line with the moral values they associated with the good city, it was important to the TED employees to keep the number of security installations to a minimum. I asked Aja if they negotiated with PET on this matter and she promptly replied, 'No you don't negotiate with PET! We tried to say, "How much will make do? It has to be secure but how far down can you accept that we go?"' PET and Copenhagen Police had the ultimate say in relation to the level of security, but on several occasions the TED employees went out to look at the specific urban spaces and used their expertise in urban planning and design to limit the number of security installations. It was also important for TED employees to use familiar elements, elements that had been part of the cityscape before the terror threat emerged. The granite blocks had been used elsewhere in the city and the planters were of a type that had existed in the city for many years, they had just added more now. Keeping the number to a minimum, using familiar elements, and making the counterterrorism measures into Copenhagener-solutions was of course a way to ensure the values of coherence and openness in the public space, but on an overall level the initiatives appear as an attempt to de-alienate the city. An attempt to return the city to what it used to be. Like Aja phrased it when the concrete blocks had just landed, 'To reverse what had been done.' Zigon argues that the primary goal of ethical work is to return from the uncomfortable moment of breakdown, and back into the unreflective comfort of familiar morality. Through ethical work of transformation and the reshaping of the counterterrorism measures, employees at TED have established a continuity from the city like it used to be to the city of today by way of the moral values associated with the public space, via the new materiality of the counterterrorism measures. Thereby, TED employees have returned from the uncomfortable moment of breakdown to the comfort of familiar morality - but have they returned to an unchanged starting point or has the urban morality changed in the process?

As part of my final data collection I recently asked Eva if she would write a few pages about TED's work with counterterrorism and public spaces. Unlike the fundamental uncertainty that Anette expressed when writing the first memorandum, Eva soon sent a clear statement on the Municipality's approach. She stated that fear should not set the agenda for the city, a sense of proportion should be kept, and there should not be overinvestment in security measures that would only make the small risk of terrorist attacks even smaller. Finally, Eva stated, 
'This is basically about taking responsibility for the public space and the city: What kind of city do we want? [...] In Copenhagen we want a city for people - an inviting city. We do not want a city that looks like a fortress where we have barricaded ourselves against potential terrorists'.

Zigon argues that the element that allows morality to develop and never stay static is the breakdown. In the case of Copenhagen, key moral values have stayed the same, perhaps even been reinforced, but the urban morality has now evolved to include an approach to security and counterterrorism. An approach based on moral values associated with the good city.

\section{Conclusions}

If one is an observer of the city — which I am - one will quite literally have seen the increase of security in cities all over the world: concrete blocks and large planters but also wedge barriers, bollards, surveillance cameras, and so forth are part of today's urban landscape. Scholars argue that security measures are constantly increasing, and decision makers legitimize this increase by way of the power of fear and moral discourses of humanitarianism, protecting democratic values, and saving lives. In this article, I have given an example of a counter movement where a public institution does not perform according to this premise. As Eva from the Municipality of Copenhagen states, fear should not set the agenda for this city.

When working with architecture and city planning in Copenhagen, one realizes that the city and its urban landscape - which is often taken for granted - has not become what it is by coincidence or chance. In this article, I have shown how city planners, architects, researchers, philanthropists, and employees at TED have worked for decades - and are still working - on creating, what they believe is, the good city. Drawing on the moral turn in anthropology, I have argued that continuous terrorist attacks in other European cities and the placing of concrete blocks in the streets of Copenhagen caused a moral breakdown and an intervention in TED's development of the good city. Rather than producing a radical, security-oriented shift in the development of the city and its public spaces, the moral breakdown engendered an ethical work of transformation. This took shape through the minimizing of the presence of security installations, thereby enabling continuity with a long-term urban morality, including values and materiality associated with liberal democracy and the Danish welfare state such as community, inclusiveness, openness, and spaciousness. In this way, the article shows how moral values serve as point of orientation in a process of recreating the good city and provides an example of how moral discourses and ethical work compose a counter movement to the systemic discourse of security.

By following the ethical work of transformation done on counterterrorism measures, it becomes evident - in a very visual way - how moral values and materiality can be intertwined. Where literature on virtue ethics presents ethical work as 
a mental practice, this article adds a material dimension to morality, which sheds new light on discussions of security and morality. Moral values become more than some fluffy ideals that can be either protected or endangered by the increase of security measures. In the case of Copenhagen, moral values are the security measures, because moral values become immanent to the materiality through ethical work of transformation. Understanding this relation between morality and materiality underlines the fact that the increase of security measures that we currently see in our cities is not just a matter of more material inventory in the streets, but a manifestation of certain moral values in the city. When securing a city like Copenhagen it is therefore important to keep in mind that one is not just reworking the materiality of the urban landscape, but reworking a firmly cultivated urban morality based on nothing less than the ancient Greek idea of public meeting places, the liberal democratic freedom to meet and discuss, and wider Danish societal values of community, inclusiveness, openness, and spaciousness.

\section{Author Bio}

Stine Ilum is an industrial PhD Fellow at Department of Anthropology, University of Copenhagen, and the Danish architecture firm SLA. Her research focuses on physical counterterrorism in Copenhagen, Oslo, and Paris, addressing topics such as fear, safety, street life, and public space as well as urban planning, architecture, and the security industry.

\section{Acknowledgements}

I would like to thank the editors, Tereza Kuldova and Jardar Østbø, and the two anonymous reviewers for their assistance in improving this article. I would also like to thank Stine Krøijer for her invaluable help.

\section{Funding}

Research for this article is funded by Innovation Fund Denmark, Realdania, and SLA.

\section{References}

Andersen et al., Mette Lis. 2002. Bedre Byrum. Copenhagen: Foreningen Realdania.

Appadurai, Arjun. 1986. "Introduction: Commodities and the politics of value." In The Social Life of Things: Commodities in cultural perspective, edited by Arjun Appadurai, 3-63. Cambridge: Cambridge University Press. https://doi.org/10.1017/CBO9780511819582.003

Arendt, Hannah. 1998[1958]. The Human Condition. Chicago: University of Chicago Press.

Astrup, Søren. 2016. "Betonklodser skal beskytte din indkøbetur på Strøget." Politiken, December 21. Accessed September 17, 2019. https://politiken.dk/ 
indland/kobenhavn/art5754292/Betonklodser-skal-beskytte-dinindk $\% \mathrm{C} 3 \%$ B 8 bstur-p $\% \mathrm{C} 3 \% \mathrm{~A} 5-\mathrm{Str} \% \mathrm{C} 3 \% \mathrm{~B} 8$ get-mod-terrorangreb

Bundegaard, Christian. 2019. "Om det offentlige rums æstetik: En beskrivelse af Forfatningspladsen i Sollér." In Byen, rummet og det fælles, edited by Carsten Thau, 435-452. Copenhagen: Arkitekturforlaget B.

Buzan, Barry, Ole Waever, and Jaap de Wilde. 1998. Security: A new framework for analysis. Boulder, CO: Rienner.

Coaffee, Jon. 2009. "Protecting the Urban: The Dangers of Planning for Terrorism." Theory, Culture \& Society 26(7-8):343-355. https://doi.org/10.1177/0263276409349656

Faubion, James D. 2001. "Toward an Anthropology of Ethics: Foucault and the Pedagogies of Autopoiesis." Representations 74(1):83-104. https://doi.org/10.1525/rep.2001.74.1.83

Fisher, David. 2013. "Does Morality Matter in Security Policy?" Survival 55(3):129-146. https://doi.org/10.1080/00396338.2013.802858

Foucault, Michel. 1984. The use of Pleasure: Volume 2 of The History of Sexuali-ty. London: Penguin Books.

Foucault, Michel. 1997. "Technologies of the self." In Ethics, subjectivity and truth, the essential works of Michel Foucault 1954-1984, edited by Paul Rabinow, 223-51. London: Penguin Books.

Gehl, Jan. 1971. Livet mellem husene: Udeaktiviteter og udemiljøer. Copenhagen: Arkitektens Forlag.

Gehl, Jan. 2013. "Fra Jane Jacobs til Liveable Cities." Dansk Byplanlaboratorium: Byplanhistorisk Skriftserie 72:8-13.

Goldstein, Daniel M. 2010. "Toward a Critical Anthropology of Security." Current Anthropology 51(4):487-517. https://doi.org/10.1086/655393

Graham, Stephen. 2010. Cities under Siege: The New Military Urbanism. London: Verso.

Habermas, Jürgen. 2009[1962]. Borgerlig Offentlighed. Copenhagen: Infor-mations Forlag.

Hesterman, Jeniffer. 2018. Soft Target Hardening: Protecting People from Attack. New York: Routledge. https://doi.org/10.4324/9780429422966

Jacobs, Jane. 2011[1961]. Life and Death of Great American Cities. New York: The Modern Library, Random House.

Klauser, Fracisco R. 2017. Surveillance \& Space. London: Sage. https://doi.org/10.4135/9781473983281

Kraul, Marie. 2019. "Byskoven på Rådhuspladsen er indviet." Politiken Byrum, March 20. Accessed September 24, 2019. https://politikenbyrum.dk/Nyheder/art7094634/Byskoven-p\%C3\%A5-R\%C3\%A5dhuspladsen-er-indviet 
Low, Setha M. 1997. "Urban Fear: Building the Fortress City." City \& Society 9(1):53-71. https://doi.org/10.1525/ciso.1997.9.1.53

Laidlaw, James. 2017. "Ethics/Morality." In The Cambridge Encyclopedia of Anthropology, edited by Felix Stein, Sian Lazar, Matei Candea, Hildegard Diemberger, Joel Robbins, Andrew Sanchez, and Rupert Stasch. Accessed October 15, 2019. https://doi.org/10.29164/17ethics

Laidlaw, James \& Jonathan Mair. 2019. "Imperfect Accomplishment: The Fo Guang Shan Short- Term Monastic Retreat and Ethical Pedagogy in Humanistic Buddhism." Cultural Anthropology 34(3):328-358. https://doi.org/10.14506/ca34.3.02

Lenz, Lyz. 2020. "U.S. rethoric around the Iran stike mirrors the 2003 logic for invading Iaq." The Washington Post, January 10. Accessed April 12, 2020. https://www.msn.com/en-us/news/opinion/us-rhetoric-around-the-iranstrike-mirrors-the-2003-logic-for-invading-iraq/ar-BBYPCRJ

Maguire, Mark, Catarina Frois, and Nils Zurawski. 2014. "The Anthropology of Security: Prospects, Retrospects and Aims." In The Anthropology of Security: Perspectives from the Frontline of Policing, Counter-terrorism and Border Control, edited by Mark Maguire, Catarina Frois and Nils Zurawski. London: Pluto Press. https://doi.org/10.2307/j.ctt183p3j7

Mattingly, Cheryl. 2012. "Two virtue ethics and the anthropology of morality." Anthropological Theory 12(2):161-184. https://doi.org/10.1177/1463499612455284

Mattingly, Cheryl \& Jason Throop. 2018. "The Anthropology of Ethics and Morality." Annual Review of Anthropology 47:475-92. https://doi.org/10.1146/annurev-anthro-102317-050129

Melander, Ronja. 2017. "Iværksætter pakker terrorsikring ind i hygge." Finans, June 17. Accessed September 17, 2019. https://finans.dk/erhverv/ ECE9659986/ivaerksaetter-pakker-terrorsikring-ind-i-hygge/?ctxref=ext

Miller, Daniel. 2010. Stuff. Cambridge: Polity Press.

Minton, Anna. 2009. Ground Control: Fear and Happiness in the Twenty-First Century City. London: Penguin Books.

Municipality of Copenhagen. 2015. Fællesskab København: Vision for 2025. Copenhagen: Københavns Kommune, Teknik og Miljø 2017. Arkitekturpolitik København 2017-2025: Arkitektur for mennesker. Copenhagen: Københavns Kommune, Teknik og Miljø.

Peterson, Marina. 2006. "Patrolling the Plaza: Privatized Public Space and The Neoliberal State in Downtown Los Angeles." Urban Anthropology and Studies of Cultural Systems and World Economic Development 35(4):355386.

Robbins, Joel. 2012. "On Becoming Ethical Subjects: Freedom, Constraint, and the Anthropology of Morality." Anthropology of This Century 5. Accessed October 15, 2019. http://aotcpress.com/articles/ethical-subjects-freedom-constraint-anthropology-morality/ 
Simpson et al., Deane. 2017. The City between Freedom and Security: Contested Public Spaces in the 21st Century. Basel: Birkhauser.

https://doi.org/10.1515/9783035607611-004

Sjørslev, Inger. 2013. Ting: I nære og fjerne verdener. Aarhus: Aarhus Universitets-forlag.

Sorkin, Michael. 2008. Indefensible Space: The Architecture of the National Insecurity State. New York: Routledge.

Zigon, Jarett. 2007. "Moral Breakdown and the ethical demand." Anthropological Theory 7(2): 131-150.

https://doi.org/10.1177/1463499607077295 